\title{
Optimal processing of greenhouse crop residues to use as energy and $\mathrm{CO}_{2}$ sources
}

\author{
J.V. Reinoso Moreno ${ }^{\mathrm{a}, *}$, G. Pinna-Hernández ${ }^{\mathrm{b}, \mathrm{c}}$, M.D. Fernández Fernández ${ }^{\mathrm{d}}$, \\ J.A. Sánchez Molina ${ }^{e}$, F. Rodríguez Díaz ${ }^{\mathrm{e}}$ J.C. López Hernández ${ }^{\mathrm{d}}$, F.G. Acién Fernández ${ }^{\mathrm{a}}$ \\ ${ }^{a}$ Marine Microalgae Biotechnology Research Group (BIO 173), Department of Engineering, University of Almería, 04120, Almería, Spain \\ ${ }^{\mathrm{b}}$ Solar Energy Research Centre (CIESOL), Joint Centre University of Almería-CIEMAT, Almería, 04120, Spain \\ ${ }^{\mathrm{c}}$ Department of Chemical Engineering, University of Almería, Almería, 04120, Spain \\ ${ }^{\mathrm{d}}$ Las Palmerillas Experimental Station, Cajamar Foundation, 04710, Almería, Spain \\ e Automatic Control, Robotics and Mechatronic Research Group (TEP 197), Department of Informatics, University of Almería, 04120 Almería, Spain
}

\section{A R T I C L E I N F O}

\section{Keywords:}

Greenhouse crop residues

Biomass

Heating systems

$\mathrm{CO}_{2}$ source

Crop Residues

Revalorization

Biomass combustion

\begin{abstract}
A B S T R A C T
This work presents the development of suitable strategies focusing on greenhouse crop residues as energy and $\mathrm{CO}_{2}$ sources for improved food production in greenhouses. The utilization of greenhouse crop residues in combustion processes for heating and carbonic enrichment in greenhouses has previously been developed and evaluated. Nevertheless, greenhouse crop residues present several problems that make it difficult to use them for these purposes. Among the characteristics that can impede their use are excessive moisture and ash contents as well as their low density. In this work, the relevant solid fuel properties for this type of biomass have been studied.

In addition, three pre-treatment strategies are proposed and evaluated, which aim to enhance the fuel quality of this biomass. These strategies were: 1 ) first relates to the drying strategy employed for reducing greenhouse crop residue moisture. 2) the second one relates to a reduction in ash content by avoiding contact with greenhouse soil and 3) mixing with other biomass kinds with better quality as solid fuels.

The assays performed showed that these strategies were successful, resulting in biomass with a high heating value, up to $26.9 \mathrm{MJ} / \mathrm{kg}$, and a lower ash content than untreated residues, with values as low as $13.0 \%$ dry weight. This value is closer to that for the standard biomass most commonly employed in direct combustion applications. The biomass produced has been verified as suitable for conventional boilers with thermal efficiencies up to $70 \%$. The methods developed allow to reuse greenhouse crop residues as greenhouse fuel, providing both heat and $\mathrm{CO}_{2}$; thus enhancing production and sustainability.
\end{abstract}

\section{Introduction}

Agricultural activity results in the generation of significant amounts of vegetal residues (Mazuela et al., 2012). Vegetal residues are considered those parts of a plant that do not have commercial value. Once they have been produced, proper management is required to avoid environmental and health problems. This management is mandatory for ensuring adequate environmental hygiene in rural areas. Poor treatment of residues can lead to a wide range of diseases and pests that potentially affect not only crops but also the animals and humans living nearby (Callejón et al., 2010; Reicosky and Wilts, 2005). Additional problems related to incorrect vegetal residues management will occur if crops are grown in cycles. When such a growing technique is used, these residues can sustain pathogens from one cycle to the next, making their control even more difficult (Bautista-Baños et al., 2006). A further issue is that the treatment of these residues has to be paid for by the growers hence it represents an expense that cuts into their profits.

The region in which this work has been focused, Almeria province, is in south- eastern Spain, where farming is the most important economic activity, accounting for more than 30,000 ha of cultivated land (Cajamar Caja Rural Agro- food studies service, 2018). This sector specializes intensively in fruit and vegetable production and makes up an important share of the market (Cajamar Caja Rural Agro- food studies service, 2018; Mancheño Losa, 2017). Therefore, this activity is significant and large- scale. Once the production stage has finished, the plants are cut down and removed from the greenhouses. Up to

\footnotetext{
*Corresponding author at: Department of Chemical Engineering, University of Almería, Carretera Sacramento s/n, E04120, Almería, Spain.

E-mail address: rmj519@ual.es (J.V. Reinoso Moreno).
} 
200kton/year (dry weight) of crop residues result from this agricultural activity. Such considerable amounts need to be properly managed (Callejón-Ferre et al., 2014).

This work is focused on the vegetal and aerial part of the plants. Once the production cycle has finished, this portion constitutes quite a significant part of the crop residues generated. It needs to be appropriately removed from the greenhouse where it has grown in order to allow for the next crop cycle. The crop residues must also be properly treated. The traditional treatment methods include: (1) disposing of it in dumps, or (2) incineration under minimally controlled conditionsboth of these lead to considerable environmental problems. More recently, certain alternatives have been developed that focus on reusing these residues - rather than being considered as residues, crop residues are potential raw material for other applications. Among the alternatives developed are: compost production, animal feed and even construction materials (Pane et al., 2013). However, more alternatives need to be developed to profitably manage the massive amounts of residues produced in Almeria. This work propose and test an alternative option, utilizing these residues as fuel in applications that require thermal heat. Such use could result in the extensive consumption of this waste product.

The use of biomass for energy has been developed significantly in recent years due to the various initiatives launched by agencies and institutions overseeing renewable energy policy. The PER (Renewable Energy Plan, 2011-2020) highlights biomass use as one of its priorities and makes a first assessment regarding the status of biomass, which is expected to be incorporated by being linked specifically to intensive agriculture. Furthermore, it is important to point out that biomass use means a double benefit for greenhouses: (1) the energy generated is used for heating (Farneti et al., 2013; Ito, 2012; Nachidi et al., 2011); and (2) the $\mathrm{CO}_{2}$ captured from the flue gas generated is used for enrichment, thus reusing $\mathrm{CO}_{2}$ emissions (Sánchez-Guerrero et al., 2005). The research group presenting this work developed a new process for using biomass as a heating and $\mathrm{CO}_{2}$ source in greenhouses (SánchezMolina et al., 2014). In this process, the biomass is used as a fuel to supply heat inside the greenhouse when necessary, especially at night to avoid low temperature stress (Liu et al., 2012; Van Der Ploeg and Heuvelink, 2005) while the $\mathrm{CO}_{2}$ produced during combustion is captured in an active carbon bed to be used during daylight hours for $\mathrm{CO}_{2}$ enrichment. If this process is applied widely to existing greenhouses, a large crop residues fraction could be reused and problems associated with its management could be avoided.

Both of the biomass use in heating devices for heating and $\mathrm{CO}_{2}$ enrichment within greenhouse atmosphere currently are applications quite well studied and sprayed between regular agricultural misusing. Nevertheless, two new challenges were faced with the research presented in this work. 1) The first one is to incorporate this specific greenhouse crop residues generated from fruit vegetable plants. Although some previous research has been done in order to study their combustion properties to be used as fuel, these research has been focused in these residues as they can be found in field at the moment they are removed with any pretreatment. Thus, the quality of these residues as solid fuel could be improved. 2) The other challenge is to develop a system which integrates heating and $\mathrm{CO}_{2}$ recovery from flue gas generated from the same fuel used to satisfice this heating energy requirements. This integration would increase significantly sustainability of the overall process comparing to applicate these two techniques separately.

In order to contemplate greenhouses crop residues as a fuel, this biomass must comply with standard requirements such as density, particle size, humidity and calorific value as well as the halogen, Sulphur and ash content, among others. There are several standards which set reference values for solid fuels obtained from biomass involved in direct combustion applications (Obernberger and Thek, 2004) along with standard EN 15234-1 (2011) ("EN 15234-1:2011. Solid biofuels- Fuel quality assurance- Part 1: General requirements,” 2011). Previous research has been carried out to study this alternative (Debdoubi et al., 2005; Demirbas, 2005; Haykiri-Açma, 2003). From these works, one can conclude that this greenhouse crop residues does not comply with most of the standards mentioned. Hence, to use greenhouse crop residues as a fuel, it is required that the pre- treatments performed allow to improve the quality of these residues to fit the minimum standards required (Debdoubi et al., 2005). In this work, the greenhouse crop residues generated from different species has been characterized and compared with other standard biomass in order to study various characteristics associated with their use in combustion devices such as boilers.

Currently, there is a specific methodology for characterizing solid biofuels set by the International Organization for Standardization (ISO) This organization, which gives references for advice on quality of different products and services, establishes various standards for each parameter related to solid fuels. Every country, through their respective national associations, reviews and adapts these standards to apply them in their territory. The respective association in the European Union is the "Comité Européen de Normalisation" (CEN, The European Committee for Standardization). In Spain, the correspondent one responsible for the preparation and application of these standards and methodologies is the "Asociación Española de la Normalización y Certificación" (AENOR, Spanish Association for Standardization and Certification). Similar standards to these are set in other countries Table 1.

The biomass characterization (moisture, ash, chloride and Sulphur contents; chemical composition and calorific value) allows to manage the useful technical information for identifying the most appropriate solution for biomass resource utilization. This consideration makes it possible to manage the utilization of these resources in a rational and controlled fashion. Accordingly, a determination of the most relevant parameters is required to select the most suitable alternative.

Excessive moisture content in fuels limits combustion efficiencythis is because a certain proportion of the thermal energy generated is wasted on vaporizing the moisture present in the biomass when it is used as a fuel. Excessive moisture content also impedes biomass ignition when initiating combustion because more thermal energy is required.

Likewise, a higher ash content impedes the combustion process by increasing ash deposition on the boiler's inner surfaces. This is a key point to consider because this ash deposition makes an extra layer on surfaces where thermal heat is exchanged between flue gas and water. This extra layer low thermal heat transference (Naganuma et al., 2013; Vassilev et al., 2010). One should have in mind that ash heat conductivity transference is nearly as high as boiler's inner surfaces which

Table 1

Different standards relevant for solid fuels derived from biomass in different countries.

\begin{tabular}{|c|c|c|}
\hline Standard & Localization & Reference \\
\hline ISO 17225-1:2014 & International & ("ISO 17225-1:2014 Solid biofuels- Fuel specifications and classes- Part 1: General requirements," 2014) \\
\hline EN ISO 17225-1:2014 & European Union & ("EN ISO 17225-1:2014 Solid biofuels- Fuel specifications and classes- Part 1: General requirements," 2014) \\
\hline DIN 51,731 & Germany & (“DIN 51731. Testing of solid biofuels, compressed untreated wood. Requirements and testing.," 1996) \\
\hline ÖNORM M 7135 & Austria & ("ÖNORM M 7135. Compressed bark in natural state, pellets and briquettes. Requirements and test specifications.," 2003) \\
\hline SS 187,120 & Sweden & ("SS 187120. Biofuels and peat, fuel pellets. Classification.," 1998) \\
\hline CTI R04/05 & Italy & ("CTI-R 04/5. Recommendation: Solid biofuels. Pellet characterization for energetic purposes," 2004) \\
\hline
\end{tabular}


often are made in metal. Thus, some regular cleaning of the equipment's internal parts is quite important. This should be made according to the ash deposition rate, given a particular case. Ash particles volatilized within the combustion chamber also slow carbon burning reaction rate.

At the same time, slag formation also from ash takes place. This last one is even less desirable than ash deposition on boiler's inner surfaces because slag becomes considerably more attached and also arise similar drawbacks. Not only ash content value has influence on slag generation quantity but also its fusion temperature and chemical composition do (Mack et al., 2018).

With regard to high heating value, it is recommendable that this value is between certain limits. Inadequately low high heating value makes these applications impractical in terms of storage space requirements whilst also potentially impeding thermal energy output in the combustion equipment.

In addition to this characterization, to increase greenhouse crop residues quality as a fuel, three strategies were proposed and tested: (1) introducing a pre-treatment for drying this greenhouse crop residues, (2) minimizing any contact between the greenhouse crop residues and the greenhouse soil at the time of removal and (3) mixing the greenhouses crop residues with other biomass kinds.

The first strategy consists of drying the greenhouses crop residues inside the greenhouse. This is done to increase the biomass quality as a fuel; it only requires a low-cost process and reduces the environmental impact. The critical factors considered when evaluating this strategy were the equilibrium moisture content achieved, the time required to achieve it and the possibility that the greenhouses crop residues might support the development of some diseases or pests while drying.

The second strategy proposed consists of minimizing greenhouses crop residues contact with the soil at the time of removal. Sand is the most common substrate used as greenhouse soil. Traditional removal methods are not careful about sand being added while the greenhouses crop residues is withdrawn. Probably the most important contribution takes place when the plants are taken outside the greenhouse after being cut at the end of the production cycle. During this operation, the plants are often in direct contact with the greenhouse soil. Since this soil is usually composed of sand, the removal method results in a significant increase in ash content. Applying methods that avoid greenhouse soil contact would reduce and homogenize the ash content in the biomass. Despite the potential and achievable decrease in ash content by applying this second strategy, one should bear in mind that greenhouses crop residues can be considered quite similar to herbaceous biomass (Demirbas, 2005; Elías-Castel, 2017; Werther et al., 2000). For example, biomass with a higher lignocellulose content like wood and those with less metal compounds in their tissues such as the ones studied in this work (olive pits and almond shells) (Karampinis et al., 2012; McKendry, 2002; Obernberger and Thek, 2004; Prochnow et al., 2009; Ververis et al., 2004).

With the above- mentioned context in mind, mixing this greenhouses crop residues with a biomass containing a lower ash content could be a feasible alternative for obtaining a fuel which performs better in combustion applications than regular greenhouses crop residues. This is the third strategy proposed and it is aimed to further enhance the biomass properties for direct combustion by its implementation. The mixture obtained would result in biomass with lower ash content than that possible using only greenhouse crop residues.

Introducing these strategies would make the characteristics of greenhouses crop residues biomass more similar to other biomass fuels, such as olive pits, almond shells and pine wood pellets, which are currently employed in direct combustion applications. Meanwhile, it should be kept in mind that greenhouses crop residues are a type of herbaceous biomass; consequently, their raw ash content is usually higher than other biomass types.

\section{Materials and methods}

\subsection{Strategies applied to increase Greenhouse Crop Residues quality as solid fuel in combustion applications}

Once the Greenhouse Crop Residues was performed it was conclude that it would be necessary to increase their quality as solid fuel so they can be employed in combustion applications. Three alternatives are proposed in accordance with what has been explained in the Introduction section. These alternative were: 1) drying (in order to reduce their moisture content) 2) avoiding contact between greenhouse residues and soil of the same greenhouse they were grown; 3) mixing with other biomass kinds with better properties as fuel.

\subsubsection{Drying experiments}

To perform the drying experiments, plants of five different crops (tomato, pepper, cucumber, zucchini and melon) were cut and left inside the greenhouses. Because of the conditions often present inside greenhouses (high temperature, low air humidity and some air flow), it is possible to dry the plants after they are cut and leave them on site. No additional heat source or artificial air circulation was applied during these experiments. The drying process lasted until the minimum possible water content was achieved; this depended on the conditions prevailing during a given experiment. The drying time was determined by monitoring the sample weight over time. For the tomato and pepper crop residues, experiments were performed at different seasons to study the influence of environmental conditions on drying kinetics. Moisture, ash content and high heating value were measured every two-three days, performing a minimum of six determinations for each drying experiment. Four plants were taken on each sampling occasion to obtain a statistically representative value.

\subsubsection{Avoiding contact between plants and greenhouse soil}

Plants of the same five crops studied (tomato, pepper, cucumber, zucchini and melon) where chosen for this expiriment. These plants were taken in the same greenhouses that the samples taken for the drying experiments. As explained in the introduction section, it was taken care to avoid to contact plants between and greenhouse soil.

\subsubsection{Mixing with biomass with better combustion properties as solid fuel}

For this experiment biomass composed by tomato greenhouse crop residues was tested. This biomass was the one with the highest ash and chloride contents. In addition tomato crops are one on the most representative in the zone where this work is focused. These tomato crop residues were pre- treated with the two alternatives previously described (drying and avoiding contact with greenhouse soil). After these pre- treatment, these residues were chopped and milled. At the same time, almond tree biomass were dried, chopped and milled. These two biomass kinds were mixed (25 almond - $75 \%$ tomato, mass percentages).The same properties were measured for this mixture in order to study its quality as biomass fuel

\subsection{Biomass characterization}

\subsubsection{Biomass samples}

Greenhouses crop residues samples were obtained from different plant species: tomato, pepper, cucumber, zucchini and eggplant. All of them are grown in the region considered (Almeria, Spain); indeed, they are the five most commonly grown species in the area. Samples were collected from two different sources: 1) crop residue disposal yards at two waste management plants and 2) directly from greenhouses. The greenhouses from which the samples were taken are located at the "Las Palmerillas" Experimental Station, a property in Almeria province belonging to the Cajamar Foundation.

Additionally, in the case of samples taken from greenhouses, these ones were collected in a way that provided a representative sample, 
Table 2

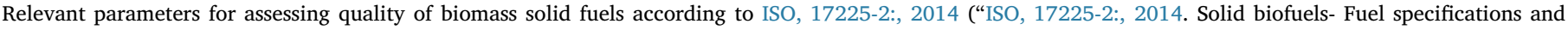
classes- Part 2: Graded wood pellets," 2014).

\begin{tabular}{|c|c|c|}
\hline Parameter & Standard & Reference \\
\hline Moisture content & ISO $18,134: 2015$ & $\begin{array}{l}\text { ("ISO, 18134-1:, 2015. Determination of moisture content- Oven dry method- Part 1: Total moisture- Reference method," } \\
\text { 2015) }\end{array}$ \\
\hline Ash content & ISO $18,122: 2015$ & (“ISO, 18122:, 2015. Solid biofuels- Determination of ash content,” 2015) \\
\hline Ash composition, Mayor elements. & ISO $16,967: 2015$ & (“ISO, 16967:, 2015- Solid biofuels- Determination of major elements- $\mathrm{Al}, \mathrm{Ca}, \mathrm{Fe}, \mathrm{Mg}, \mathrm{P}, \mathrm{K}, \mathrm{Si}, \mathrm{Na}$ and Ti," 2015) \\
\hline Ash fusion temperature & ISO 540:2008 & ("ISO 540:, 2008. Hard coal and coke- Determination of ash fusibility," 2008) \\
\hline High heating value & ISO $18,125: 2017$ & ("ISO, 18125:, 2017. Solid biofuels- Determination of calorific value," 2017) \\
\hline Chloride and sulfur content & ISO $16,994: 2016$ & ("ISO, 16994:, 2016. Solid biofuels- Determination of total content of sulfur and chlorine," 2016) \\
\hline
\end{tabular}

keeping the same mass proportion between stem and leaves that one would find in such plants. To manage this, once the samples were taken and dried, they were chopped. This pre-treatment procedure for the analysis of a given sample is also necessary, in accordance to that stated in the ISO 18,135 protocol ("ISO, 18135:, 2017 Solid Biofuels- Sampling," 2017). Furthermore, 3 biomass examples used more extensively in usual combustion applications were acquired from local suppliers in order to compare their properties. These examples were pine wood pellets, olive pits and almond shells.

\subsubsection{Characterization methods}

Bearing in mind the various considerations exposed at the introduction section, seven various characteristics were considered as references, and were determined for all the samples taken: moisture, ash and halogens content (chloride and sulfur); high heating value; biomass and ash chemical composition; and ash melting temperature. The protocols followed and specific equipment used to determine all of these parameters are showed Table 2.

Respect to their calorific value, as it has been mentioned before, the determination of these parameter was performed through the protocol detailed in Table 2 ("ISO 18,125:2017. Solid biofuels- Determination of calorific value," 2017). The measurement obtained is the high heating value. This one considers the water amount generated from this combustion reaction, in which the hydrogen chemical species initially present in the biomass oxidize, this value is the one obtained if the latent heat for this amount of water generated is not subtracted (Hartmann, 2012) Eq. (1).

$\Delta H_{\text {hhv } \_r m}=(1-H) \Delta H_{\text {sup } \_d b}+H \cdot \lambda_{v}$

Where " $\Delta \mathrm{H}_{\text {hhv_rm" }}$ " is the high heating value with raw moisture content of a given sample as it is found at the moment it is taken; being $\mathrm{H}$ its moisture content. At the other hand, " $\Delta \mathrm{H}_{\text {hhv_db" is high heating value }}$ considering that the sample is completely dried (dried basis) and " $\lambda_{\mathrm{v}}$ ": is the water latent heat.

\section{Results and discussion}

\subsection{Strategies applied to increase Greenhouse Crop Residues quality as solid fuel in combustion applications}

\subsubsection{Drying experiments inside the greenhouse}

The kinetics of drying assays performed inside the greenhouse after the plants were cut are presented in Fig. 1. In this figure, one can observe how the moisture content progresses over time while the drying experiments are performed. These data show that it is possible to reduce the greenhouse crop residues water content to values closer to those required by the standards set for solid fuel obtained from biomass, under the air conditions usually found inside a greenhouse (the relative humidity and temperature) ("ISO 17225-2: 2014- Solid biofuels- Fuel specifications and classes- Part 2: Graded wood pellets," 2014).

For the different assays performed in the same season (i.e. the weather conditions were similar during the time period considered), no significant differences were observed for the drying rate of the different plant species studied (Fig. 1a). On the other hand, studying the results related to the experiments performed in different seasons, significant differences were observed for the same plant species. These differences concerned the drying rate (the rate of water loss) and the equilibrium moisture content achieved- the higher the temperature and the lower the relative humidity, the faster the water loss and the lower the equilibrium moisture content values.

Regarding the drying pre-treatment process, this could promote the decay of the vegetal matter, transforming it into compounds with a higher oxidation level; this is because biomass reaches high temperatures in an atmosphere where oxygen is present for a relatively long time (weeks). Furthermore, microorganism activity should be taken into account as it also performs oxidation processes; hence, the ash content might be enhanced. However, from the data collected in these experiments, it can be stated that the increase of ash content in the biomass types we studied were almost negligible (Fig. 1b).

The limited influence that ash content had on drying might be explained by two factors. The first is that the temperature reached inside the greenhouse during the drying period was lower than that for the usual drying processes; for example, vegetable and fruit drying, with average values around $65^{\circ} \mathrm{C}$, (Di Scala and Crapiste, 2008; Doymaz and Pala, 2002; El-Sebaii et al., 2002). The second factor is that the water content was lower, at values that limited microorganism activity. The low water content level at which this activity became limited was reached relatively quickly. Despite this minimal influence, the remaining ash content was still higher than that for biomass types usually employed for combustion purposes, as observed in the biomass characterization study.

\subsubsection{Avoiding contact between plants and greenhouse soil}

The biomass characteristics relevant to direct combustion are compared in Fig. 2 (moisture ash, Sulphur and chloride contents, high heating value) for the three biomass kinds pre-treated (tomato, pepper residues, and tomato + sand mixture) as mentioned in the materials and methods section. As one can observe, implementing this strategy in the handling procedure can achieve a considerable ash content reduction, of up to $52.1 \%$.

\subsubsection{Mixing with biomass with better combustion properties as solid fuel}

The properties of the mixtures evaluated are presented in Fig. 3. As was intended, the Ash content of the raw material can be considerably decreased by mixing this biomass with others that have a lower ash content. Meanwhile, the heat heating value of the raw biomass (with its raw water content) remained similar to that found in the types of biomass most commonly used in combustion applications.

Respect to the chloride and sulfur content, the values corresponding to pepper crop residues were inferior to tomato crop residues. A significant point is that there is an appreciable decrease when avoiding contact between greenhouse soil and crop residues for the case of tomato. This can be explained from a possible addition of $\mathrm{Cl}$ compounds if no precaution is taken during the removal. Meanwhile, Chloride and Sulfur content observed in the mixture assayed of $25 \%$ almond tree$75 \%$ tomato crop residues were similar to pepper crop residues. 

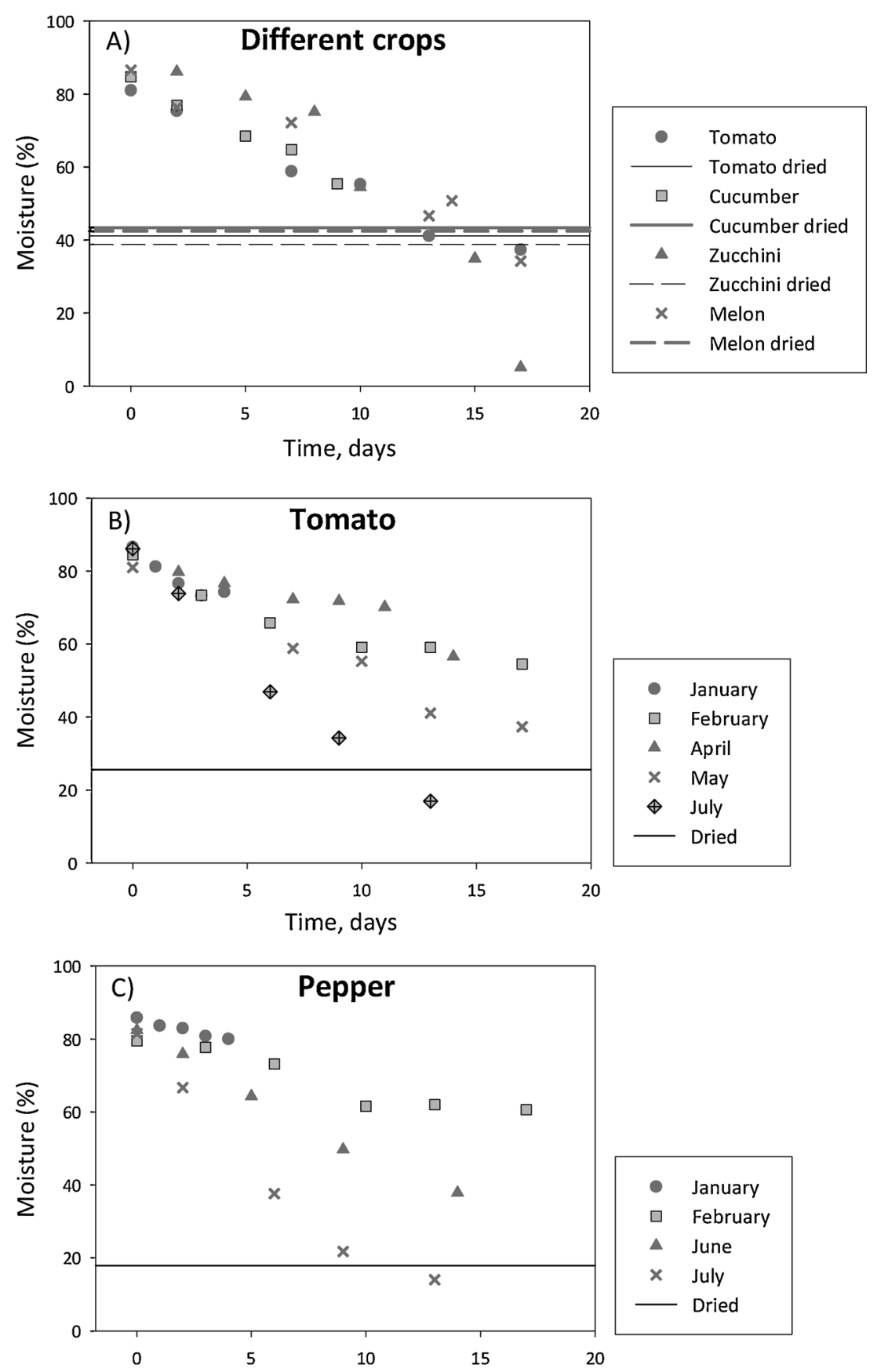

Time, days

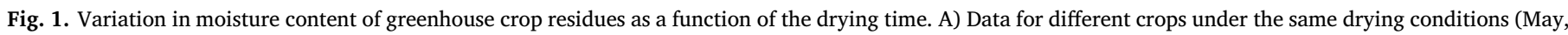
inside greenhouse); B) Data from the tomato crop at different dates throughout the year; C) Data from the pepper crop at different dates throughout the year.

Nevertheless this Chloride and Sulfur content values were significantly higher than what is recommended according to corresponding standards ("ISO 17225-2: 2014. Solid biofuels- Fuel specifications and classes- Part 2: Graded wood pellets," 2014) and other biomass kinds usually employed as pine pellets (Dare et al., 2001). Additional pretreatments aiming to lower these levels would be interesting. One problem given with chloride compounds emissions is that their deposition on boiler's inner surfaces significantly decrease the equipment life expectancy. Although it would be possible to use more resistant material for these surfaces it would be necessary to mind the limit values of compounds emitted into atmosphere, set on correspondent legislation. Inclusion of almond tree biomass lower these levels, nevertheless they still remain appropriate for direct combustion application.

On review of the ash biomass composition, relevant data is presented at Fig. 4. Calcium, Potassium, Magnesium and Phosphorus were the most prevalent. Analyzing the most remarkable differences, the Si content was considerable lower for those samples "free of sand" (contact with greenhouse soil was avoided). This result was in accordance to the ash content reduction observed respect to the biomass removal method, thus it is reasonable to conclude that the main contribution to ash content was given by sand added during its removal (being $\mathrm{SiO}_{2}$, the sand main compound). Moreover, some elements concentration were significantly higher in the case of a particular biomass source, for 

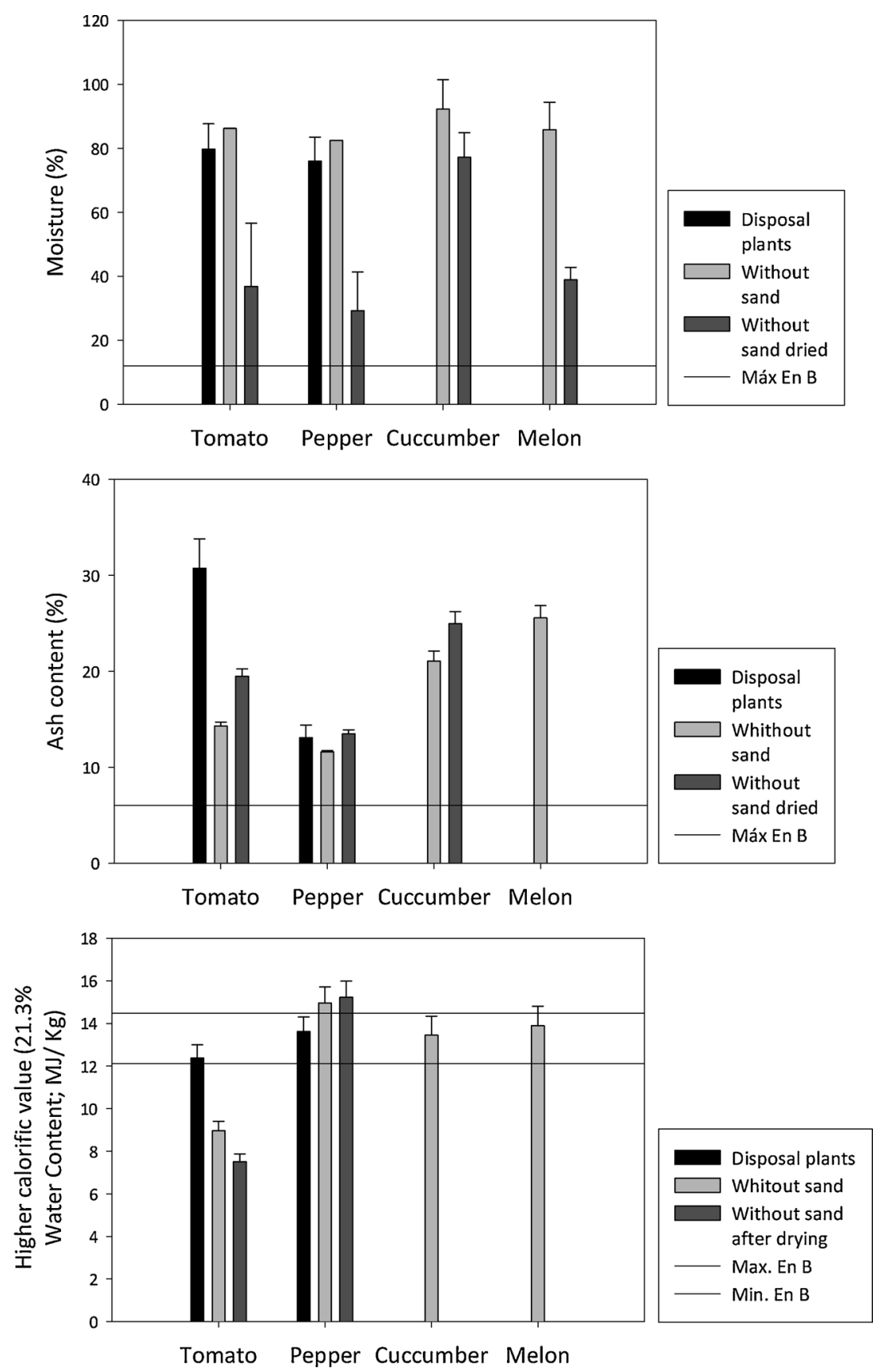

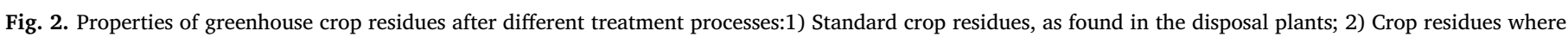
contact with greenhouse soil was avoided (without sand); 3) Similar to Treatment 2 but with additional drying (without sand after drying).

example $\mathrm{K}$ for peeper crop residues, Na for tomato crop residues and $\mathrm{Ca}$ for tomato crop residues + almond.

Two cases were particularly interesting. 1) The first one is the fact that some reduction was observed for some elements with higher concentration between tomato crop residues "free of sand" and the respective one to which none precaution was taken to avoid their contact with greenhouse soil. This observation can be explained considering that there was a considerable mass reduction corresponding to the entire sand amount which it was avoided to add. Bearing in mind this mass it is expectable that the rest of compounds concentrations become different. 2) The second one was the increase of Ca concentration observed for the case of tomato crop residues + almond assortment respect to the tomato crop residues. From this observation it can be concluded that Ca concentration of almond assortment biomass should be considerable, this is reasonable considering that this is woody biomass (Obernberger and Thek, 2004).

At the same time at Fig. 5, it is presented data relevant for analyzing the melting behavior of ash obtained for the various biomass kinds studied (sintering, sphere, hemisphere and melting temperature). This factor should be regarded, the melting behavior is useful to predict how the slag formation and volatile tendencies inside boilers are. Analyzing these data, tomato crop residues and almond tree assortment mixtures presented melting temperature appreciably higher. This could be explained by their differences concerning their chemical composition.

On Review of the data obtained, it is reasonable to state that this mixing has contributed to enhance greenhouse crop residues quality in terms of direct combustion applications. Nonetheless, one can argue that it is necessary to use fuel with better characteristics to obtain this mixture; although, thanks to this introduction, biomass with higher quality was obtained, being capable of using this biomass in a 


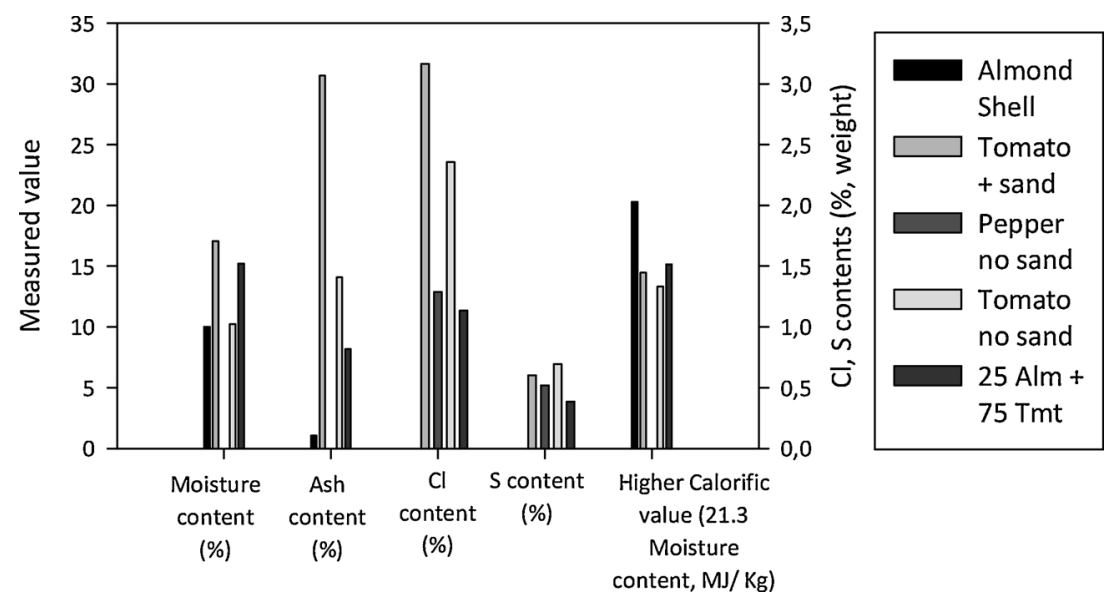

Fig. 3. Properties of almond shells, pepper crop residues without sand and pellets obtained from tomato crop residues with and without sand, and in mixture with almond tree wood assayed as a method to improve the quality of the final pellets obtained.
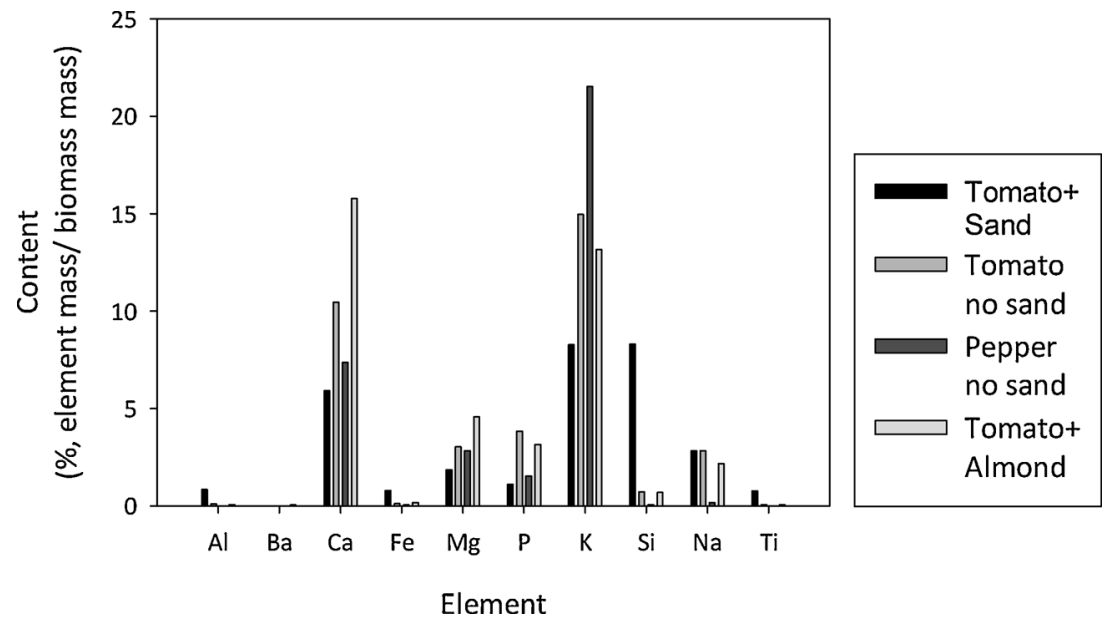

Fig. 4. Ash elements composition of the different biomass samples studied (tomato crop residues with and without sand, in mixture with almond tree wood and pepper crop residues.

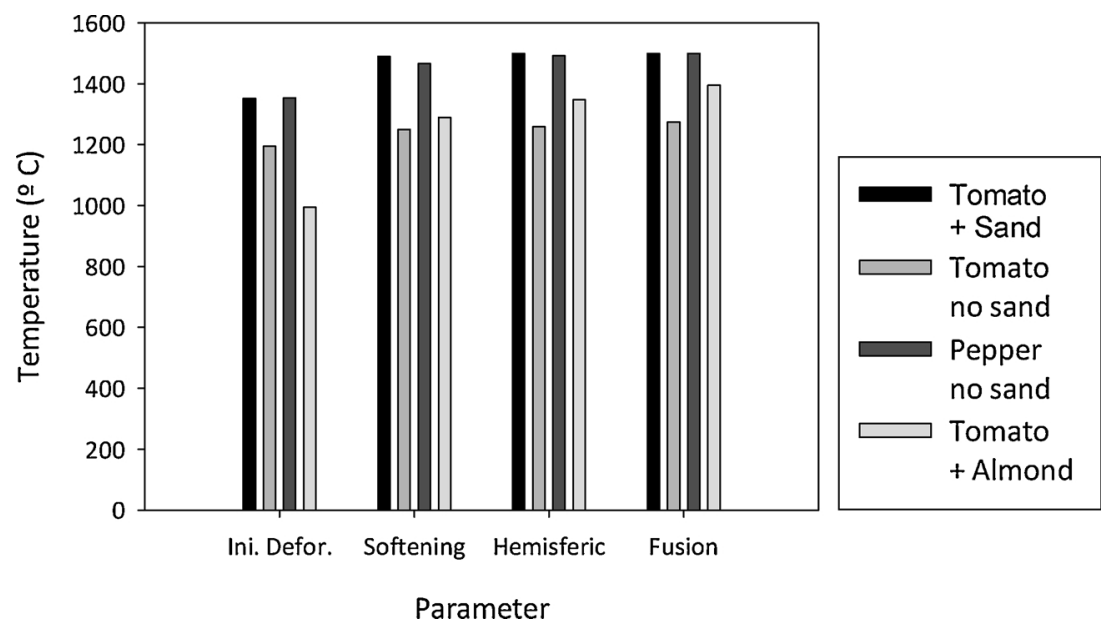

Fig. 5. Sintering, sphere, hemisphere and melting of ash obtained from combustion of the different biomass samples studied (tomato crop residues with and without sand, in mixture with almond tree wood and pepper crop residues.

commercial direct combustion device. Considering that initially more problems and worse performance were presented in the direct combustion applications, this can be seen as a novel alternative for greenhouse crop residues treatment. Furthermore, this strategy makes this biomass reutilization feasible, reinforcing its potential use in energy production.

An additional point, to consider and study, is whether there might be potential differences between the different greenhouse crop residues plant tissues; e.g., different properties might be found in the leaves and stems if they are to be considered for use as biomass solid fuels. 

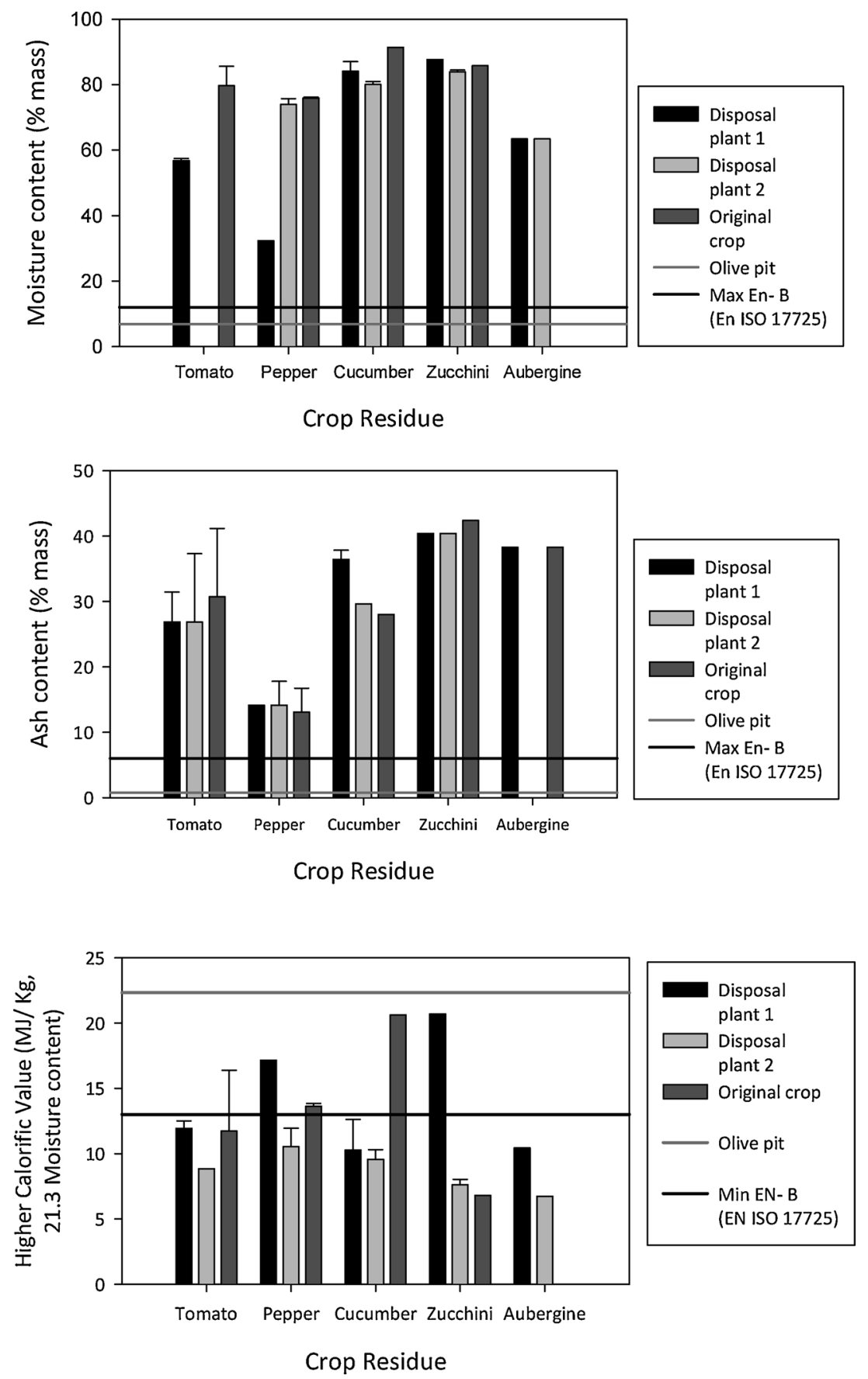

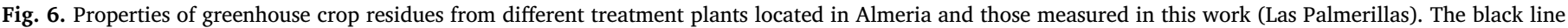
plots the EN ISO B standard minimum or maximum requirements while the olive pit properties are represented by the single grey line.

Research focused on this issue has been carried out for other plant species, demonstrating that some differences exist between the various vegetal tissues and organs (Boon et al., 2012; Ververis et al., 2004). Therefore, it might be expected that some tissues or parts of the plant species this work focused on could be more appropriate for direct combustion applications. Nevertheless, if this is the case, it would be necessary to develop further alternatives to reutilize the parts of the crop residues that are inappropriate for such a purpose.

\subsection{Biomass characterization}

The results obtained from the biomass characterization (Fig. 8) are compared with values determined for olive pits and wood pellets, which are solid biomass fuels used extensively in combustion applications as a thermal energy source. In addition, the minimum requirements defined by the European Comitee for Standardization ("EN ISO, 17225-1:, 2014 Solid biofuels- Fuel specifications and classes- Part 1: General requirements," 2014) are plotted in this figure. The data show that the moisture content of raw greenhouse crop residues is much higher than for olive pits and wood pellets, with values ranging from 58 to $80 \%$. Although certain differences existed between the values from different locations, the main factor was the crop type. The high moisture content means it is not possible to use this greenhouses crop residues as a fuel without further pre-treatment. Nevertheless, the moisture content observed can vary based on the time elapsed since the plants were cut. This suggests that implementing a prior drying step (such as the one 
Table 3

Most relevant data related to boiler combustion performance of a mixture of tomato pellets and almond wood. ${ }^{*} \mathrm{Nm}^{3}: \mathrm{m}^{3}$ under standardized conditions $\left(24^{\circ} \mathrm{C}, 1 \mathrm{~atm}\right)$.

\begin{tabular}{lll}
\hline Primary air supply & 0.0195 & $\mathrm{~m}^{3} / \mathrm{s}$ \\
\hline Secondary air supply & 0.0145 & $\mathrm{~m}^{3} / \mathrm{s}$ \\
Biomass feed inlet & 15 & $\mathrm{Kg} / \mathrm{h}$ \\
Flue gas temperature & 224.0 & $\stackrel{\circ}{\mathrm{C}}$ \\
Thermal losses & 34.9 & $\%$ \\
{$\left[\mathrm{CO}_{2}\right]$} & 3.2 & $\% \mathrm{Vol}$. \\
{$[\mathrm{CO}] 0 \% \mathrm{O}_{2}$} & 13836.5 & $\mathrm{mg} / \mathrm{Nm}^{3 *}$ \\
{$\left[\mathrm{NO}_{\mathrm{X}}\right] 0 \% \mathrm{O}_{2}$} & 1036.1 & $\mathrm{mg} / \mathrm{Nm}^{3 *}$ \\
{$\left[\mathrm{SO}_{2}\right] 0 \% \mathrm{O}_{2}$} & 519.9 & $\mathrm{mg} / \mathrm{Nm}^{3 *}$ \\
${\mathrm{Top}[\mathrm{CO}] 0 \% \mathrm{O}_{2}}_{\mathrm{Top}\left[\mathrm{NO}_{\mathrm{x}}\right] 0 \% \mathrm{O}_{2}}^{3974.4}$ & $\mathrm{mg} / \mathrm{Nm}^{3 *}$ \\
Top $\left[\mathrm{SO}_{2}\right] 0 \% \mathrm{O}_{2}$ & 3815.4 & $\mathrm{mg} / \mathrm{Nm}^{3 *}$ \\
\hline
\end{tabular}

tested in this work) could make the biomass suitable for combustion.

Concerning the greenhouses crop residues moisture content, other researchers (Callejón-Ferre et al., 2011) have reported moisture content values diverging in a narrower range, 80.9 (Pepper) - 93.0\% (Zucchini). However, the samples studied in that work were taken from a specific source and were measured just after plant cutting to determine the initial moisture content found in greenhouses while the plants are alive. Focusing only on "original crop" samples, taken for the same purpose as in the other work, the range was closer, with values ranging between 75.9-91.4\% (Pepper and cucumber, respectively). The differences observed (although relatively small) can be explained by the source influence. One should bear in mind that variables related to the greenhouse environment can influence these plants, such as 1) air temperature, 2) air humidity (these two are also related to the season the experiments were performed), 3) water availability in the soil (the watering rate) and even soil composition. All these factors can influence the moisture content (and other properties), as pointed out in other research on other crops (Williams et al., 2016).

The ash content ranged from 14.1 to $40.4 \%$; this is much higher than that for olive pits or wood pellets. No significant differences were observed between values from different locations. As with the moisture levels, the main factor determining the ash content was the crop type. Pepper had the lowest ash content whereas zucchini had the highest. The previously cited authors (Callejón-Ferre et al., 2011) reported similar values although they found relatively minor differences, with values ranging from 13.2 (eggplant) to $29.8 \%$ (zucchini). The same factors that have influence on moisture content also have on the ash content. At the same time, soil composition can be especially important for this parameter. Plants growing in soils with greater salinity need to accumulate more inorganic salts to maintain the ion-cation gradient between the roots and the areal portion of the plant (Gallegos-Cedillo et al., 2016).

Regarding the high heating value, this value is within the range measured for other biomass materials such as olive pits and wood pellets. The data presented in Fig. 6 are standardized with respect to a reference moisture content value $(21.3 \%)$. All experimental high heating values were re- estimated considering this moisture content value to be the reference rather than the corresponding real one. This re- estimation was done to make the comparison easier between the different values observed for all the biomass studied. The reference moisture content value which were selected was an average for the dried greenhouse crop residues under proper weather conditions in the greenhouse environment. After this standardization, the high heating value data ranged from $6.7 \mathrm{MJ} / \mathrm{kg}$ (eggplant) to $20.7 \mathrm{MJ} / \mathrm{kg}$ (zucchini). The same conclusion can be made for this variable; namely, the crop type is the most influential factor, more so than the sample source. According to these results, the high heating value of greenhouse crop residues is acceptable for use as a fuel. Nevertheless, it would be advisable to lower its water and ash content.
The other researchers referenced above (Callejón-Ferre et al., 2011) reported the higher heating value for the biomass studied in that work to be ranged from 12.6 (cucumber) to $16.5 \mathrm{MJ} / \mathrm{Kg}$ (eggplant). The values observed in the present work presented more extensive variation. These differences might be the result of the same factors discussed for moisture and ash content. It might be relevant to bear in mind that the case presenting the most significant observable difference (eggplant) was the biomass sample with the lowest moisture content. This could be related to the longer time elapsed between cutting down the plant and taking the samples. It is important to remember that biomass samples collected from disposal plants may have been stored for different time periods. Thus, it is reasonable to argue that, in the case of the eggplant samples, the organic compounds were exposed to a more intensive decay process, which decreased more their high heating value than for the other samples studied.

At the other hand, the combustion performance data obtained for the boiler and these biomass mixtures are presented in

Table 3. Several positive aspects were observed in this experiment: 1) stable combustion was upheld, 2) no serious problems arose following ignition of these mixtures and, 3) $\mathrm{NO}_{\mathrm{X}}$ and $\mathrm{SO}_{2}$ emissions were below the relevant legal limits (Andalucian Goverment, 2011). One should point out that these outcomes were achieved in a device which is mainly designed to work with the standard biomass types (pine pellets and olive pits) with higher quality for direct combustion applications.

Despite the positive points explained before, 1) the CO level was above the limit set by current legislation and 2) although the thermal efficiency was acceptable, it would be appropriate to manage a reduction in this value. Consequently, additional actions should be addressed, mainly: 1) changes to the combustion chamber size, 2) the thickness of its coating and 3) the gas flow pattern inside it.

\section{Conclusions}

The vegetal crop residues generated by agricultural activity could provide an alternative renewable energy source. The different actions tested in this work have demonstrated the feasibility of using this type of biomass as fuel for direct combustion applications. This work studied the possibility of using greenhouse crop residues as a feasible solid fuel alternative for temperature control boilers in greenhouses in Almeria and its surrounding area, with the aim of increasing production yield and economic profits.

However, this alternative can also be used elsewhere. Residues generated from different kinds of crops could be used as fuel if adequate pre- treatments, such as those proposed in this article, are performed. Considering the enormous volume of vegetal crop residues generated worldwide, this alternative has considerable potential.

In this work, it is demonstrated that by applying three pre- treatments (drying inside greenhouses, avoiding contact with soil and mixing with other biomass kinds, one can increase and homogenize greenhouse crop residues, providing a high heating value and lower ash content; thus enhancing their quality as a solid fuel, achieving quality levels close to the other biomass fuels most commonly used in direct combustion applications. These pre- treatments were: drying the cut plants in the same greenhouse as they were grown, once the production cycle has finished, changing the removal method of these greenhouse crop residues to reduce their contact with the greenhouse soil, and mixing these greenhouse crop residues with biomass that has a lower ash content to lower the level present in the raw material.

\section{References}

Bautista-Baños, S., Hernández-Lauzardo, A.N., Velázquez-del Valle, M.G., HernándezLópez, M., Ait Barka, E., Bosquez-Molina, E., Wilson, C.L., 2006. Chitosan as a potential natural compound to control pre and postharvest diseases of horticultural commodities. Crop Prot. 25, 108-118. https://doi.org/10.1016/j.cropro.2005.03. 010 .

Boon, E.J.M.C., Struik, P.C., Engels, F.M., Cone, J.W., 2012. Stem characteristics of two 
forage maize (Zea mays L.) cultivars varying in whole plant digestibility. IV. Changes during the growing season in anatomy and chemical composition in relation to fermentation characteristics of a lower internode. NJAS - Wageningen J. Life Sci. 59, 13-23. https://doi.org/10.1016/j.njas.2011.05.001.

Cajamar Caja Rural Agro- food studies service, 2018. Análisis De La Campaña Hortifrutícola En Almería (In Spanish: Crop Year Analysis in Almería).

Callejón, A.J., Carreño, A., Sánchez-Hermosilla, J., Pérez, J., 2010. Evaluación de impacto ambiental de centro de transformación y gestión de residuos sólidos agrícolas en la provincia de Almería (España). Inf. la Construcción 62, 79-93. https://doi.org/10. 3989/ic.08.028.

Callejón-Ferre, A.J., Velázquez-Martí, B., López-Martínez, J.A., Manzano-Agugliaro, F., 2011. Greenhouse crop residues: energy potential and models for the prediction of their higher heating value. Renew. Sustain. Energy Rev. 15, 948-955. https://doi. org/10.1016/j.rser.2010.11.012.

Callejón-Ferre, A.J., Carreño-Sánchez, J., Suárez-Medina, F.J., Pérez-Alonso, J., Velázquez-Martí, B., 2014. Prediction models for higher heating value based on the structural analysis of the biomass of plant remains from the greenhouses of Almería (Spain). Fuel 116, 377-387. https://doi.org/10.1016/j.fuel.2013.08.023.

CTI-R 04/5, 2004. Recommendation: Solid Biofuels. Pellet Characterization for Energetic Purposes.

Dare, P., Gifford, J., Hooper, R.J., Clemens, A.H., Damiano, L.F., Gong, D., Matheson, T.W., 2001. Combustion performance of biomass residue and purpose grown species. Biomass Bioenergy 21, 277-287. https://doi.org/10.1016/S0961-9534(01)00039-3.

Debdoubi, A., El Amarti, A., Colacio, E., 2005. Production of fuel briquettes from esparto partially pyrolyzed. Energy Convers. Manage. 46, 1877-1884. https://doi.org/10. 1016/j.enconman.2004.09.005.

Demirbas, A., 2005. Potential applications of renewable energy sources, biomass combustion problems in boiler power systems and combustion related environmental issues. Prog. Energy Combust. Sci. 31, 171-192. https://doi.org/10.1016/j.pecs. 2005.02.002.

Di Scala, K., Crapiste, G., 2008. Drying kinetics and quality changes during drying of red pepper. LWT - Food Sci. Technol. 41, 789-795. https://doi.org/10.1016/j.lwt.2007. 06.007.

DIN 51731, 1996. Testing of Solid Biofuels, Compressed Untreated Wood. Requirements and Testing.

Doymaz, İ., Pala, M., 2002. Hot-air drying characteristics of red pepper. J. Food Eng. 55, 331-335. https://doi.org/10.1016/S0260-8774(02)00110-3.

Elías-Castel, X., 2017. Is considered the biomass as an energetic alternative?tLe. Engineenring J. DYNA 82, 41-43.

El-Sebaii, A.A., Aboul-Enein, S., Ramadan, M.R.I., El-Gohary, H.G., 2002. Empirical correlations for drying kinetics of some fruits and vegetables. Energy 27, 845-859. https://doi.org/10.1016/S0360-5442(02)00021-X.

EN 15234-1, 2011. Solid Biofuels- Fuel Quality Assurance- Part 1: General Requirements, 2011.

EN ISO 17225-1, 2014. Solid Biofuels- Fuel Specifications and Classes- Part 1: General Requirements, 2014

Farneti, B., Schouten, R.E., Qian, T., Dieleman, J.A., Tijskens, L.M.M., Woltering, E.J., 2013. Greenhouse climate control affects postharvest tomato quality. Postharves Biol. Technol. 86, 354-361. https://doi.org/10.1016/j.postharvbio.2013.07.004.

Gallegos-Cedillo, V.M., Urrestarazu, M., Álvaro, J.E., 2016. Influence of salinity on transport of nitrates and potassium by means of the xylem sap content between roots and shoots in young tomato plants. J. Soil Sci. Plant Nutr. 16, 991-998. https://doi. org/10.4067/S0718-95162016005000072.

Hartmann, H., 2012. Solid biofuels solid biofuel, fuels and their characteristics. In: Meyers, R.A. (Ed.), Encyclopedia of Sustainability Science and Technology. Springer, New York, New York, NY, pp. 9821-9851. https://doi.org/10.1007/978-1-44190851-3_245.

Haykiri-Açma, H., 2003. Combustion characteristics of different biomass materials. Energy Convers. Manage. 44, 155-162. https://doi.org/10.1016/S0196-8904(01) 00200-X.

ISO 16967, 2015. Solid Biofuels- Determination of Major Elements- Al, Ca, Fe, Mg, P, K, $\mathrm{Si}, \mathrm{Na}$ and $\mathrm{Ti}, 2015$.

ISO 16994, 2016. Solid Biofuels- Determination of Total Content of Sulfur and Chlorine, 2016.

ISO 17225-1, 2014. Solid Biofuels- Fuel Specifications and Classes- Part 1: General Requirements, 2014.

ISO 17225-2, 2014. Solid Biofuels- Fuel Specifications and Classes- Part 2: Graded Wood Pellets, 2014.

ISO 18122, 2015. Solid Biofuels- Determination of Ash Content, 2015.

ISO 18125, 2017. Solid Biofuels- Determination of Calorific Value, 2017.

ISO 18134-1, 2015. Determination of Moisture Content- Oven Dry Method- Part 1: Total
Moisture- Reference Method, 2015.

ISO 18135, 2017. Solid Biofuels-Sampling, 2017.

ISO 540, 2008. Hard Coal and Coke- Determination of Ash Fusibility, 2008.

Ito, K., 2012. Greenhouse temperature control with wooden pellet heater via model predictive control approach. 2012 20th Mediterranean Conference on Control and Automation, MED 2012 - Conference Proceedings 1542-1547. https://doi.org/10. 1109/MED.2012.6265858.

Karampinis, E., Vamvuka, D., Sfakiotakis, S., Grammelis, P., Itskos, G., Kakaras, E., 2012 Comparative study of combustion properties of five energy crops and Greek lignite. Energy Fuels 26, 869-878. https://doi.org/10.1021/ef2014088.

Liu, Y.F., Qi, M.F., Li, T.L., 2012. Photosynthesis, photoinhibition, and antioxidant system in tomato leaves stressed by low night temperature and their subsequent recovery. Plant Sci. 196, 8-17. https://doi.org/10.1016/j.plantsci.2012.07.005.

Mack, R., Kuptz, D., Schön, C., Hartmann, H., 2018. Combustion behaviour and slagging tendencies of kaolin additivated agricultural pellets and of wood-straw pellet blends in a small scale boiler. European Biomass Conference and Exhibition Proceedings. pp. $408-417$.

Mancheño Losa, S.L.P.J.J., 2017. Surface and Production Statics of Cultives. Vegetables. in: Anuario De Estadística Del Ministerio De Agricultura, Pesca Y Alimentación 2016 2017 (In Spanish: 2016- 2017 Staditicts Anuary of Agricultural, Fishing and Feed Spanish Ministery 2016- 2017). Agricultural, Fishing and Feed Spanish Ministery.

Mazuela, P., Urrestarazu, M., Bastias, E., 2012. Vegetable waste compost used as substrate in soilless culture. Crop Prod. Technol. https://doi.org/10.5772/29221.

McKendry, P., 2002. Energy production from biomass (part 1): overview of biomass. Bioresour. Technol. 83, 37-46. https://doi.org/10.1016/S0960-8524(01)00118-3.

Nachidi, M., Rodríguez, F., Tadeo, F., Guzman, J.L., 2011. TakagiSugeno control of nocturnal temperature in greenhouses using air heating. ISA Trans. 50, 315-320. https://doi.org/10.1016/j.isatra.2010.11.007.

Naganuma, H., Ikeda, N., Ito, T., Matsuura, M., Nunome, Y., Ueki, Y., Yoshiie, R., Naruse, I., 2013. Reduction mechanisms of ash deposition in coal and/or biomass combustion boilers. Fuel 106, 303-309. https://doi.org/10.1016/j.fuel.2012.11.017.

Obernberger, I., Thek, G., 2004. Physical characterisation and chemical composition of densified biomass fuels with regard to their combustion behaviour. Biomass Bioenergy 27, 653-669. https://doi.org/10.1016/j.biombioe.2003.07.006.

ÖNORM M 7135, 2003. Compressed Bark in Natural State, Pellets and Briquettes. Requirements and Test Specifications.

Pane, C., Piccolo, A., Spaccini, R., Celano, G., Villecco, D., Zaccardelli, M., 2013. Agricultural waste-based composts exhibiting suppressivity to diseases caused by the phytopathogenic soil-borne fungi Rhizoctonia solani and Sclerotinia minor. Agric., Ecosyst. Environ., Appl. Soil Ecol. 65, 43-51. https://doi.org/10.1016/j.apsoil.2013. 01.002.

Prochnow, A., Heiermann, M., Plöchl, M., Amon, T., Hobbs, P.J., 2009. Bioenergy from permanent grassland - A review: 2. Combustion. Bioresour. Technol. 100, 4945-4954. https://doi.org/10.1016/j.biortech.2009.05.069.

Reicosky, D.C., Wilts, A.R., 2005. CROP-RESIDUE MANAGEMENT. Encyclopedia of Soils in the Environment. Elsevier, pp. 334-338. https://doi.org/10.1016/B0-12-3485304/00254-X.

Sánchez-Guerrero, M.C., Lorenzo, P., Medrano, E., Castilla, N., Soriano, T., Baille, A., 2005. Effect of variable $\mathrm{CO}_{2}$ enrichment on greenhouse production in mild winter climates. Agric. For. Meteorol. 132, 244-252. https://doi.org/10.1016/j.agrformet. 2005.07.014.

Sánchez-Molina, J.A., Reinoso, J.V., Acién, F.G., Rodríguez, F., López, J.C., 2014 Development of a biomass-based system for nocturnal temperature and diurnal $\mathrm{CO} 2$ concentration control in greenhouses. Biomass Bioenergy 67, 60-71. https://doi.org/ 10.1016/j.biombioe.2014.04.015.

SS 187120, 1998. Biofuels and peat, fuel pellets. Classification.

Van Der Ploeg, A., Heuvelink, E., 2005. Influence of sub-optimal temperature on tomato growth and yield: a review. J. Hortic. Sci. Biotechnol. 80, 652-659.

Vassilev, S.V., Baxter, D., Andersen, L.K., Vassileva, C.G., 2010. An overview of the chemical composition of biomass. Fuel 89, 913-933. https://doi.org/10.1016/j.fuel. 2009.10.022.

Ververis, C., Georghiou, K., Christodoulakis, N., Santas, P., Santas, R., 2004. Fiber dimensions, lignin and cellulose content of various plant materials and their suitability for paper production. Ind. Crops Prod. 19, 245-254. https://doi.org/10.1016/j. indcrop.2003.10.006.

Werther, J., Saenger, M., Hartge, E.-U., Ogada, T., Siagi, Z., 2000. Combustion of agricultural residues. Prog. Energy Combust. Sci. 26, 1-27. https://doi.org/10.1016/ S0360-1285(99)00005-2.

Williams, C.L., Westover, T.L., Emerson, R.M., Tumuluru, J.S., Li, C., 2016. Sources of biomass feedstock variability and the potential impact on biofuels production. Bioenergy Res. 9, 1-14. https://doi.org/10.1007/s12155-015-9694-y. 